\title{
Variations in nearshore waves along Karnataka, west coast of India
}

\author{
V Sanil Kumar*, Glejin Johnson, G Udhaba Dora, \\ Sajiv Philip Chempalayil, Jai Singh and P Pednekar \\ Ocean Engineering, National Institute of Oceanography (Council of Scientific 83 \\ Industrial Research), Dona Paula, Goa 403 004, India. \\ *Corresponding author.e-mail: sanil@nio.org
}

\begin{abstract}
Wind wave spectra were recorded simultaneously at three shallow (water depth 7-9 $\mathrm{m}$ ) locations (Malpe, Honnavar and Karwar) along the $200 \mathrm{~km}$ stretch of the state of Karnataka in 2009 during 27 April-24 May (representing conditions prior to onset of the Indian summer monsoon), 12 June-8 July (monsoon), and 1-31 October (post-monsoon). Each spectrum was based on data recorded for half an hour using a waverider buoy. The paper describes characteristics of the spectra and the wave parameters derived from the spectra. Both reveal the dramatic changes that occur in the wave field due to the summer monsoon. The changes were virtually identical at all the three locations suggesting that the wave characteristics described here are representative of the conditions that exist along the coast of Karnataka State, west coast of India.
\end{abstract}

\section{Introduction}

The wind field over the north Indian Ocean shows dramatic temporal changes. During JuneSeptember, a time generally referred to as the summer monsoon, the general direction of winds north of the equator is southwesterly and its strength is significantly larger than that during the rest of the year (figure 1). During November-March, referred to as the winter monsoon, winds over the same region have overall northeasterly direction. October and April-May are times of transition between the two monsoons (Shetye et al 1985). This seasonal cycle of winds leads to a seasonal cycle in wind wave field over the north Indian Ocean, both over the open sea and over coastal areas (Kumar and Anand 2004; Semedo et al 2011). However, the nature of this seasonal variability is not well described. Particularly needed are good quality wave measurements using standard instrumentation such as waverider buoys. The need for such measurements has been felt most acutely along the coast of India where there are a number of development projects being undertaken in the offshore areas. These projects need good knowledge of wave field to estimate design parameters of offshore structures.

This paper reports the data that were collected simultaneously at three locations to describe the wave climate along the coast of Karnataka State in India which lies along the central portion of the west coast of India (figure 2). The data were collected for a month during June-July to represent the summer monsoon conditions and during October (April-May) to represent the conditions that exist towards the beginning (end) of the rest of the year. The April-May observations are referred to as representative of the pre-monsoon conditions

Keywords. Seas; swells; wind waves; Arabian Sea; mixed sea state; wave spectrum. 


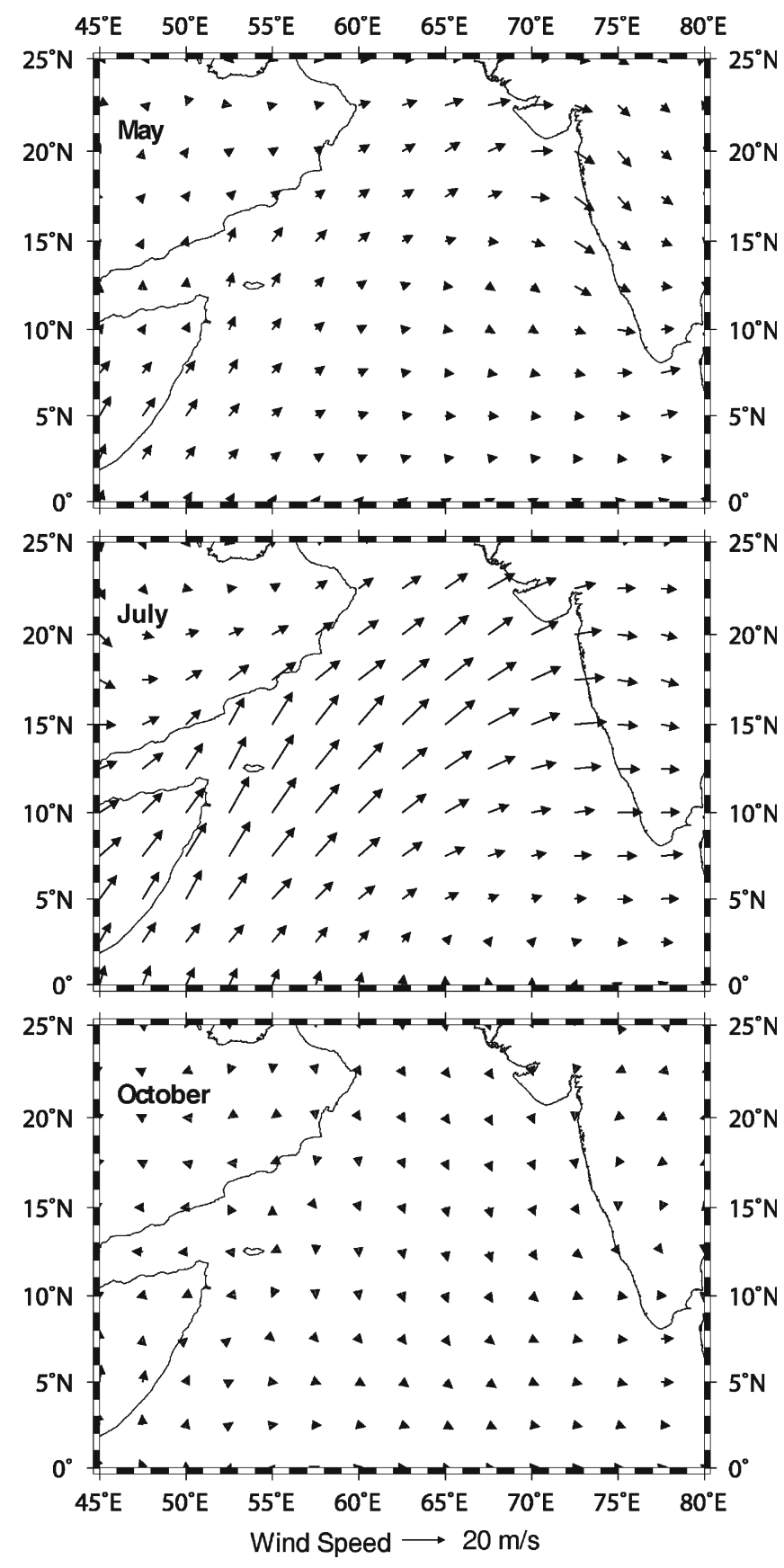

Figure 1. The climatological wind field over the north Indian Ocean during May (pre-monsoon), July (summer monsoon) and October (post-monsoon). The source of the data is US Navy Marine Climatic Atlas of the World Indian Ocean 1976 (Washington DC: US Government Printing Office) Vol. 3.

and October as post-monsoon. Section 2 describes the data collection locations and the data analysis. The results of the study are presented in section 3 .

\section{Materials and methods}

The waves at three locations, in 9-m water depth off Malpe and off Honnavar, and in 7-m water depth off Karwar were measured using the Datawell directional waverider buoy (Stephen and Kollstad 1991). The coastal segment along the study region is bounded by Western Ghats in the east and the Arabian Sea in the west. The continental shelf off Karnataka has an average width of $80 \mathrm{~km}$. The coastline at Karwar is inclined to the west by $24^{\circ}$ from the true north. The bathymetry here has depth contours aligned approximately parallel to the coastline. The depth contours of 20,50, 100 and $200 \mathrm{~m}$ occurs at 10, 30, 75 and $100 \mathrm{~km}$ off Karwar and 12, 48, 90 and $108 \mathrm{~km}$ off Malpe (figure 2). The coastline at Honnavar and Malpe are inclined to the west by $17^{\circ}$ from the true north. There are a few islands off the coast, the major one being St. Mary's Island, $4 \mathrm{~km}$ off the coast near Malpe. The rivers joining the Arabian Sea along the Karnataka coast are Kali, Gangavali, Aganashini, Sharavathi, Hangarkatta and Gangolli. Sand bars are seen in most of the estuaries. The coast is exposed to the seasonally reversing monsoon winds and the annual rainfall is $3 \mathrm{~m}$. The tides in this region are mixed semi-diurnal dominant, the range of which increases towards the north (Kumar et al 2011a). The monthly-mean sea level along the west coast of India exhibits a seasonal oscillation that is related to reversal of geostrophic currents along the coast (Shankar 2000). The monthly mean sea level at Karwar varies from $1.06 \mathrm{~m}$ in September to $1.3 \mathrm{~m}$ in January. The average tidal range at Karwar is $1.58 \mathrm{~m}$ during springs and $0.72 \mathrm{~m}$ during neaps. During the summer monsoon along the west coast of India, significant wave height $\left(H_{m 0}\right)$ up to $6 \mathrm{~m}$ has been reported (Kumar et al 2006), $H_{m 0}$ is normally $<1.5 \mathrm{~m}$ during rest of the period (Kumar et al 2003).

The measurements reported in this paper were carried out during 27 April-24 May 2009 (representing pre-monsoon condition), 12 June-8 July 2009 (representing summer monsoon) and 1-31 October 2009 (representing post-monsoon). The data were recorded for 30 minutes duration at a frequency of $1.28 \mathrm{~Hz}$ at every half an hour during the measurements. The wave spectrum was obtained through Fast Fourier Transform (FFT). FFT of six series, each consisting of 256 measured vertical elevations of the buoy data, were added to obtain the spectra. The high frequency cut-off was at $0.58 \mathrm{~Hz}$ and the resolution was $0.005 \mathrm{~Hz}$. The significant wave height $\left(H_{m 0}\right)$ which equals $4 \sqrt{m_{0}}$ and the mean wave period $\left(T m_{02}\right)$ which equals $\sqrt{m_{0} / m_{2}}$ were obtained from the wave spectrum. Where $m_{n}$ is the $n$th order spectral moment and is given by $m_{n}=\int_{0}^{\infty} f^{n} S(f) d f, n=0$ and $2, S(f)$ is the spectral energy density at frequency $f$. The period corresponding to the maximum spectral energy, i.e., spectral peak period $(T p)$ was estimated from the wave spectrum. Other parameters computed from 


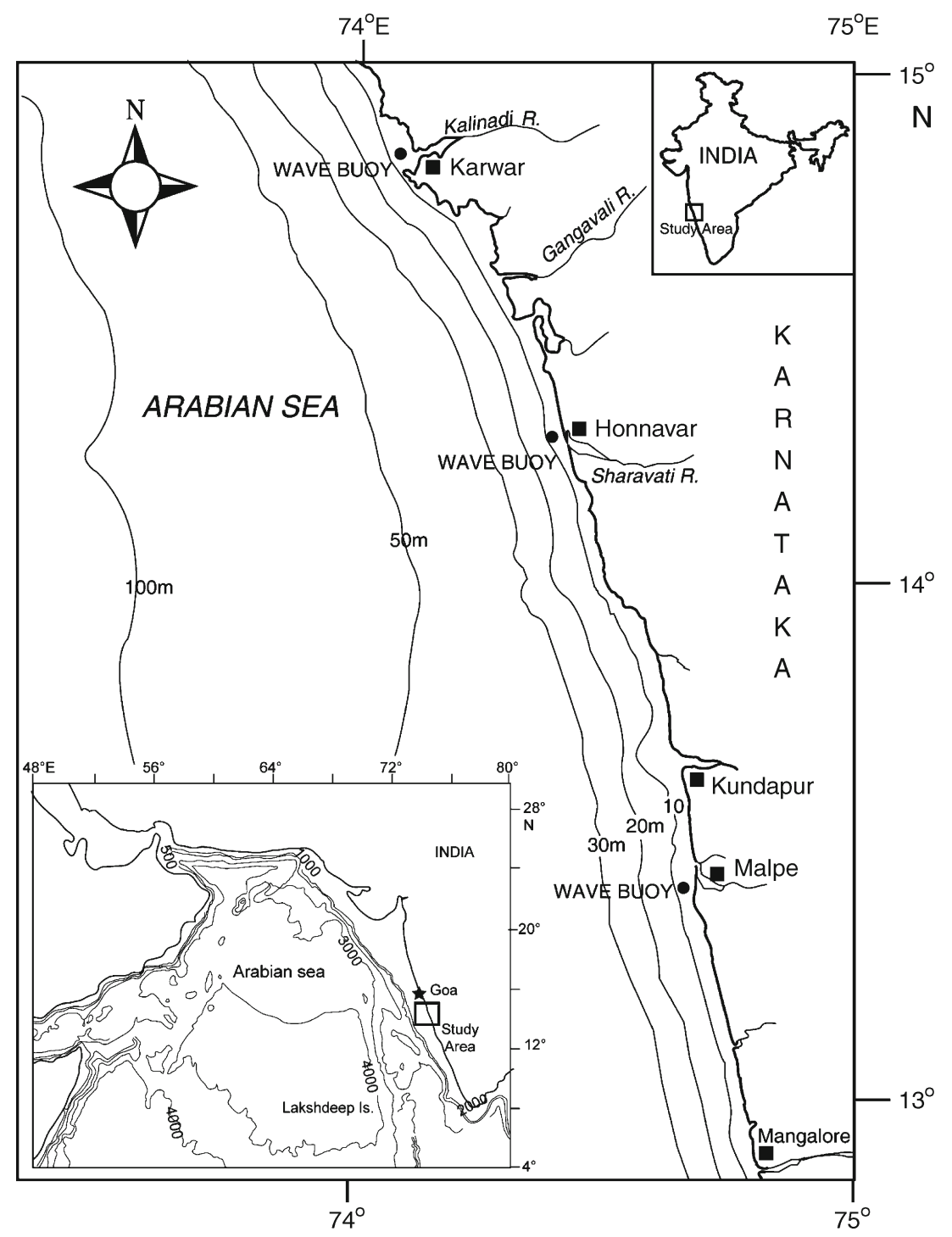

Figure 2. Locations where the wave measurements are done for the study. North Indian Ocean including the Lakshadweep islands are shown in the inset. These islands are important because the observed measurement area is in the shadow of the islands during summer monsoon and therefore have the potential to have an impact on the observed wave field. The location referred in Kumar et al (2010) is off Goa at $14 \mathrm{~m}$ water depth.

the spectrum were spectral narrowness parameter $(\nu)$ (Longuet-Higgins 1975) and the maximum spectral energy. Zero-crossing analysis of the surface elevation time series was used to estimate $H_{1 / 3}$ and maximum wave height $\left(H_{\max }\right)$.

The wind seas and swells from the measured data were separated through the method described by Portilla et al (2009). Portilla et al (2009) proposed a 1-D separation algorithm on the basis of the assumption that the energy at the peak frequency of a swell system cannot be higher than the value of a PM spectrum (Pierson and Moskowitz 1964) with the same peak frequency. The algorithm calculates the ratio $\left(\gamma^{*}\right)$ between the peak energy of a wave system and the energy of a PM spectrum at the same frequency. If $\gamma^{*}$ is above the threshold value of 1 , the system is considered to represent wind sea, else it is taken to be swell. Wind sea and the swell parameters are computed by integrating over the respective spectral parts.

\section{Results and discussions}

Contour plots of the normalized wave spectral energy density (figures 3-5) at the three locations where the observations were carried out show predominance of wind sea during the pre-monsoon period than that during other periods. Normalization of each spectrum was carried out by dividing the wave spectral energy density by the maximum spectral energy density. Time series of the 

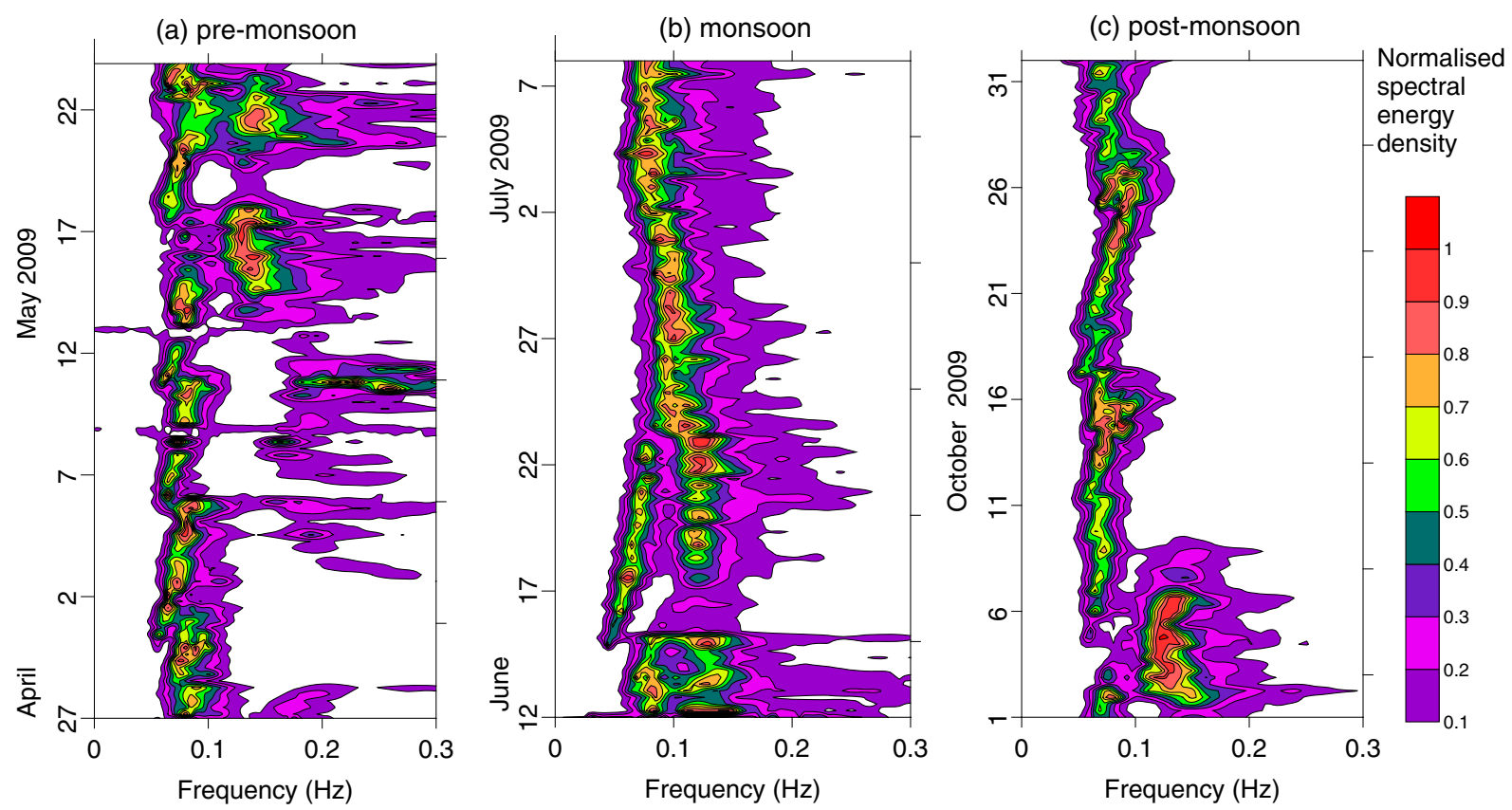

Figure 3. Contour plot of normalised spectral energy density during (a) pre-monsoon, (b) monsoon, and (c) post-monsoon at Karwar. On 14 June 2009 at 0900 hrs, the waverider buoy drifted from deployed location and re-deployed at 1400 hrs. Hence there is discontinuity in the data.

(a) pre-monsoon

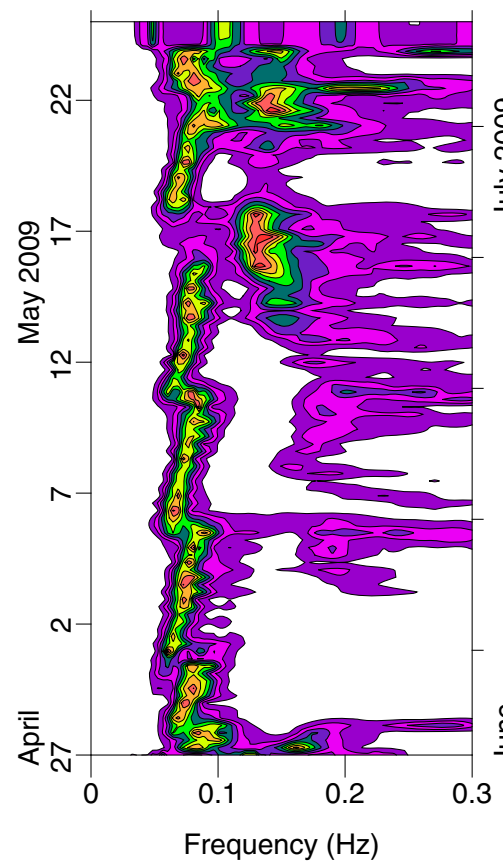

(b) monsoon

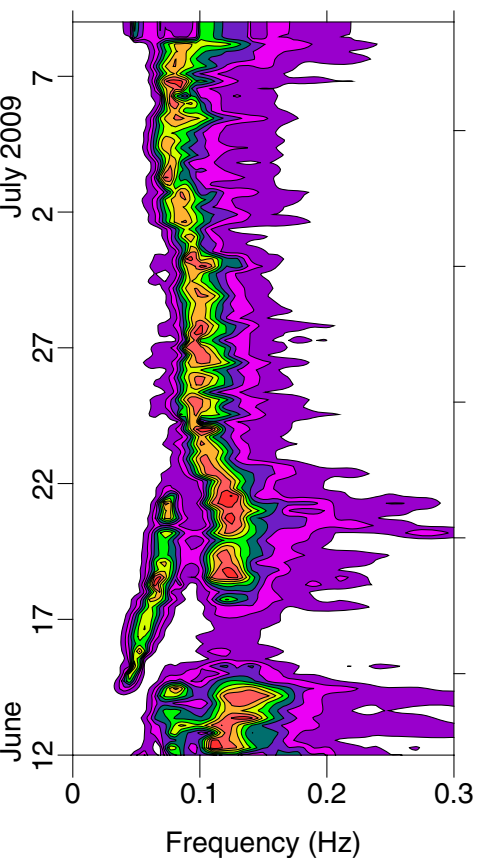

(c) post-monsoon

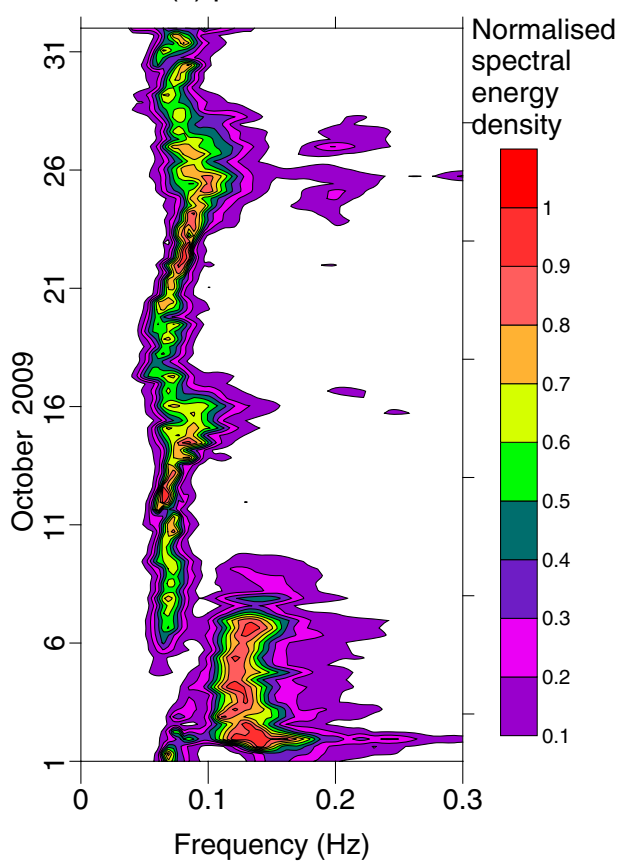

Figure 4. Contour plot of normalized spectral energy density during (a) pre-monsoon, (b) monsoon, and (c) post-monsoon at Honnavar.

maximum spectral energy density that was used to normalize each spectrum is presented in figure 6. Maximum spectral energy density during monsoon is much higher (up to $35 \mathrm{~m}^{2} / \mathrm{Hz}$ ) than that (less than $5 \mathrm{~m}^{2} / \mathrm{Hz}$ ) during the other periods.
Spectral energy due to higher frequencies (0.15$0.25 \mathrm{~Hz}$ ) was predominant during May (figures 3a, $4 \mathrm{a}$ and $5 \mathrm{a}$ ) because the coastal winds along the study region have a distinct signal due to sea breeze during pre-monsoon period (Neetu et al 2006). This 
(a) pre-monsoon

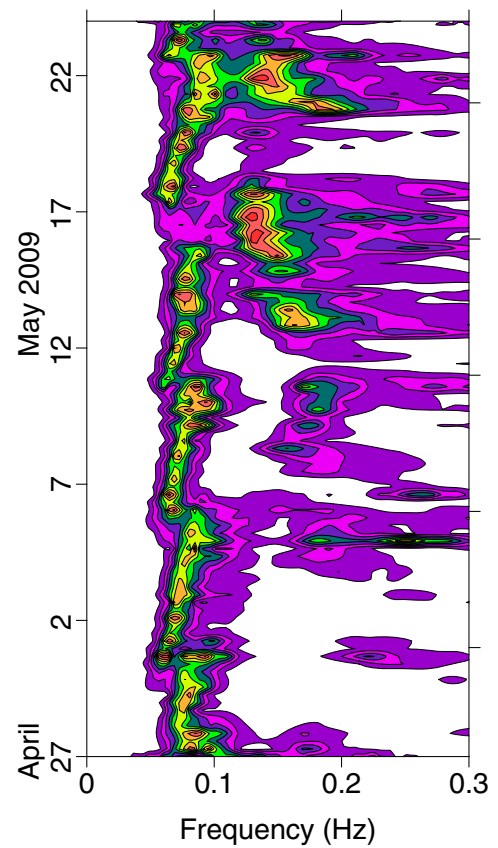

(b) monsoon

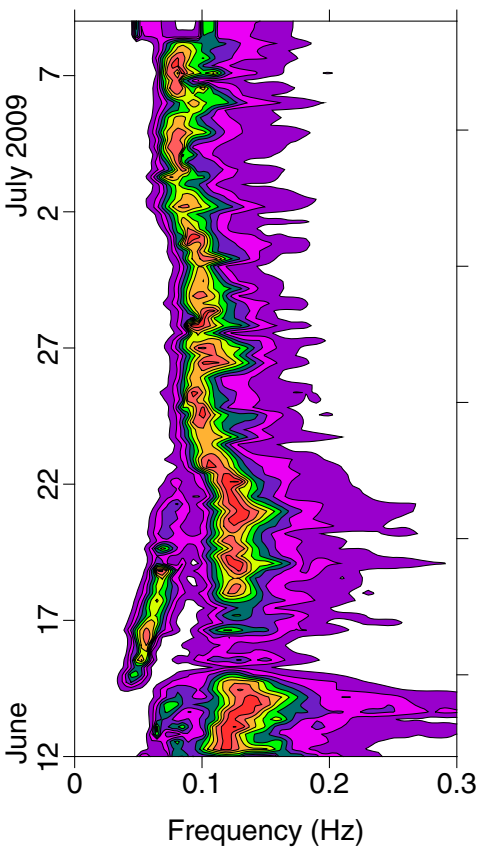

(c) post-monsoon

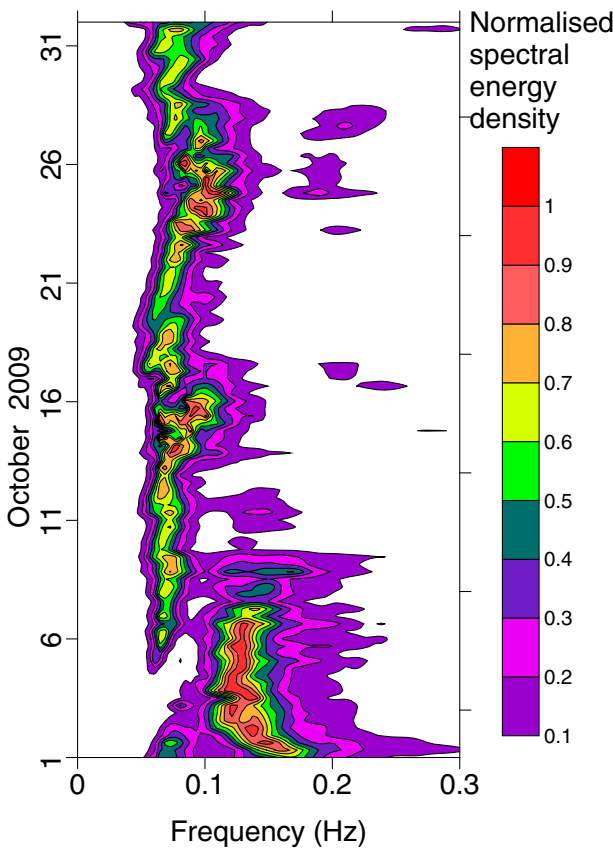

Figure 5. Contour plot of normalized spectral energy density during (a) pre-monsoon, (b) monsoon, and (c) post-monsoon at Malpe.

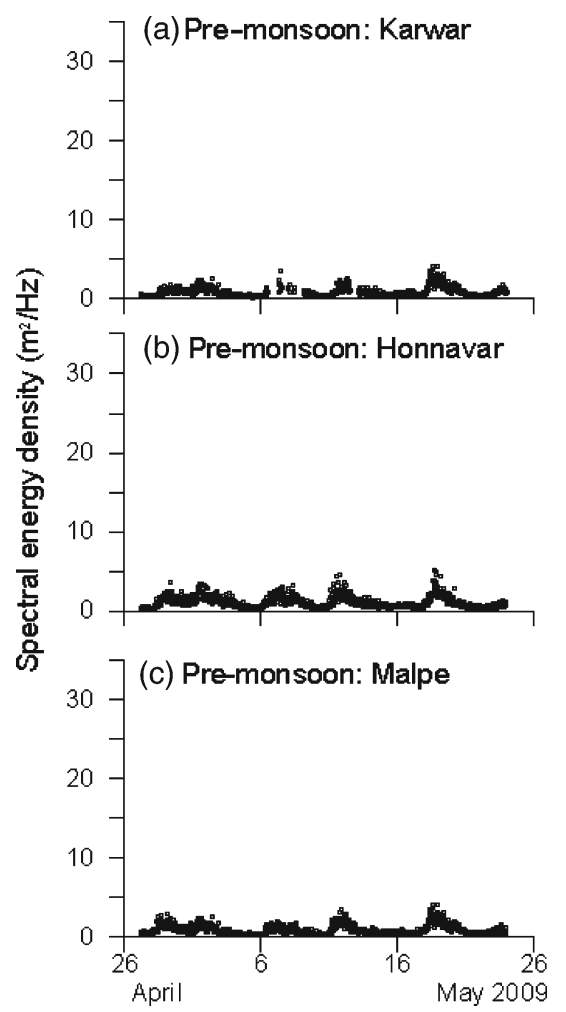

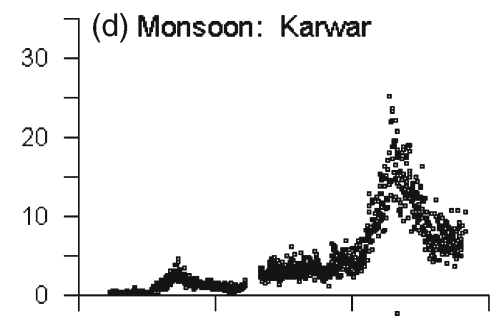

(e) Monsoon: Honnavar:"
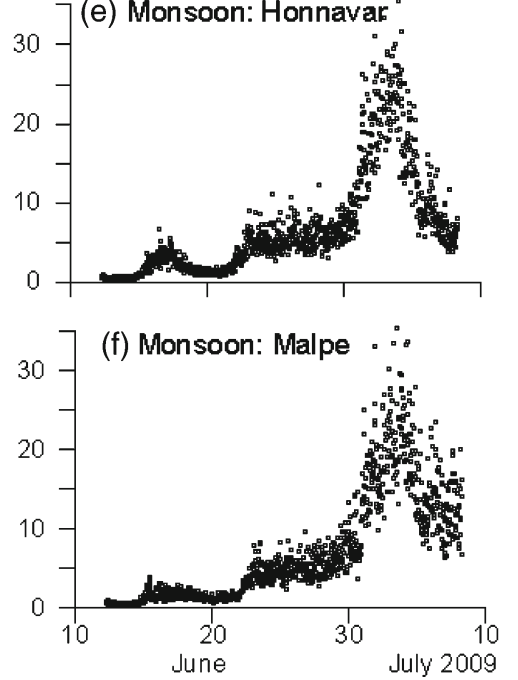

(g) Post-monsoon: Karwar
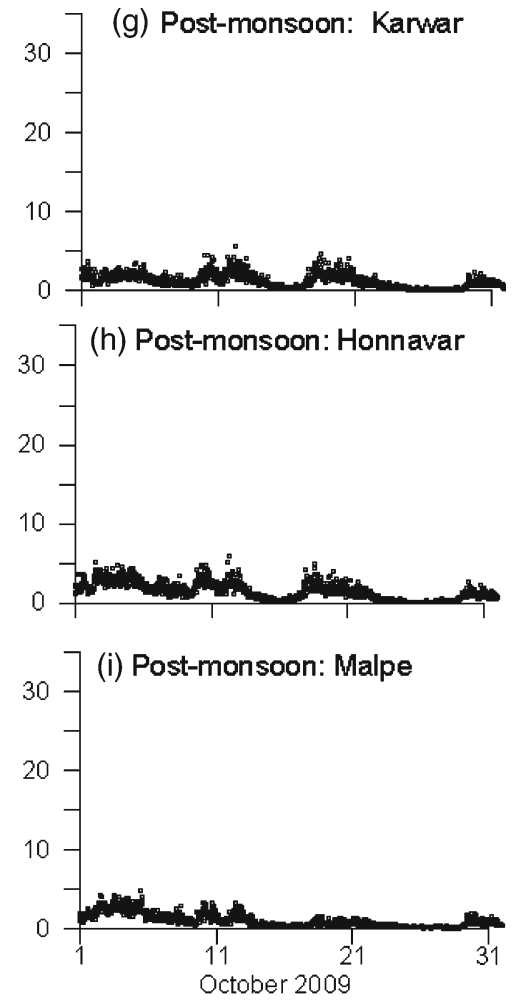

Figure 6. Time series plot of maximum spectral energy density at Karwar, Honnavar and Malpe during pre-monsoon, monsoon and post-monsoon period.

makes the sea during this part of the year stand out from the swell. During May, swells (waves with periods larger than about $10 \mathrm{~s}$ ) arrive in distinct trains lasting about 5 days. In addition to the trains of swells, there are two (three at Malpe) episodes of higher frequency waves. These could be 
due to the storms that usually occur in the north Indian Ocean prior to onset of the monsoon.

In the beginning of the monsoon, the spectral peak was around $0.12-0.13 \mathrm{~Hz}$ (figures $3 \mathrm{~b}, 4 \mathrm{~b}$ and $5 \mathrm{~b}$ ) and it shifted towards lower frequencies $(0.07-0.09 \mathrm{~Hz})$ during the peak monsoon period (28 June-8 July). The shifting of peak frequency towards the lower frequency is considered to be one of the wave growth characteristics along this coast at this time. Long period ( $>18 \mathrm{~s}$ ) swells were present during $7.5 \%$ of the time during the monsoon period (15-18 June) at all the locations. During June--July there was one episode of a wave train with period $>10 \mathrm{~s}$, similar to the wave trains observed during May. Other than this one episode, the waves seem to be the consequence of waves generated by winds of the summer monsoon. Contribution to the wave field initially could be from the region close to the coastline (could even be generated locally), but as time progresses, swells from the region farther off are expected to start contributing. Further studies are needed to verify these conjectures.

The observed spectra are narrow banded during $70 \%$ of the time during October (post-monsoon period) with the spectral energy density varying between 0.042 and $0.134 \mathrm{~Hz}$ (figures 3c, 4c and 5c). During this period, contribution of the wind sea is negligible. During the first week of October the wave field is similar to that found in June-July. Later the wave field is dominated by wave trains of swells similar to those seen in May, but now the trains last longer ( $\sim 10$ days).

Since the wave spectra were multi-peaked having swells and locally generated waves (wind seas), the swell components and the seas were separated and the wave parameters of sea and swell at Honnavar are presented in figure 7 . Since there is no large difference between the wave parameters at the three locations, the wave parameters for the central location (Honnavar) alone are presented in figures 7 9. During the monsoon, average $H_{m 0}$ due to swell was $1.6 \mathrm{~m}$ and that due to wind sea was $0.9 \mathrm{~m}$. $H_{m 0}$ up to $4.3 \mathrm{~m}$ was recorded during the measurement period. Average $H_{m 0}$ during the monsoon was $1.9 \mathrm{~m}$ and during the rest of the period was $0.8 \mathrm{~m}$. The percentage of swell in the measured wave field was $50 \%$ during the pre-monsoon period and was $72 \%$ during the monsoon and post-monsoon period (table 1). A noteworthy feature in the observations is the dominance of swells $(\sim 72 \%)$ during the monsoon season. During this season, dominance of seas is expected along the west coast of India due to the prevailing high winds. In order to confirm the dominance of swells during monsoon, we examined the wave data collected at Honnavar during the years 2008 and 2010 and found that the swells dominated ( $\sim 73 \%$ in 2008 and $\sim 77 \%$ in 2010 ) during all the
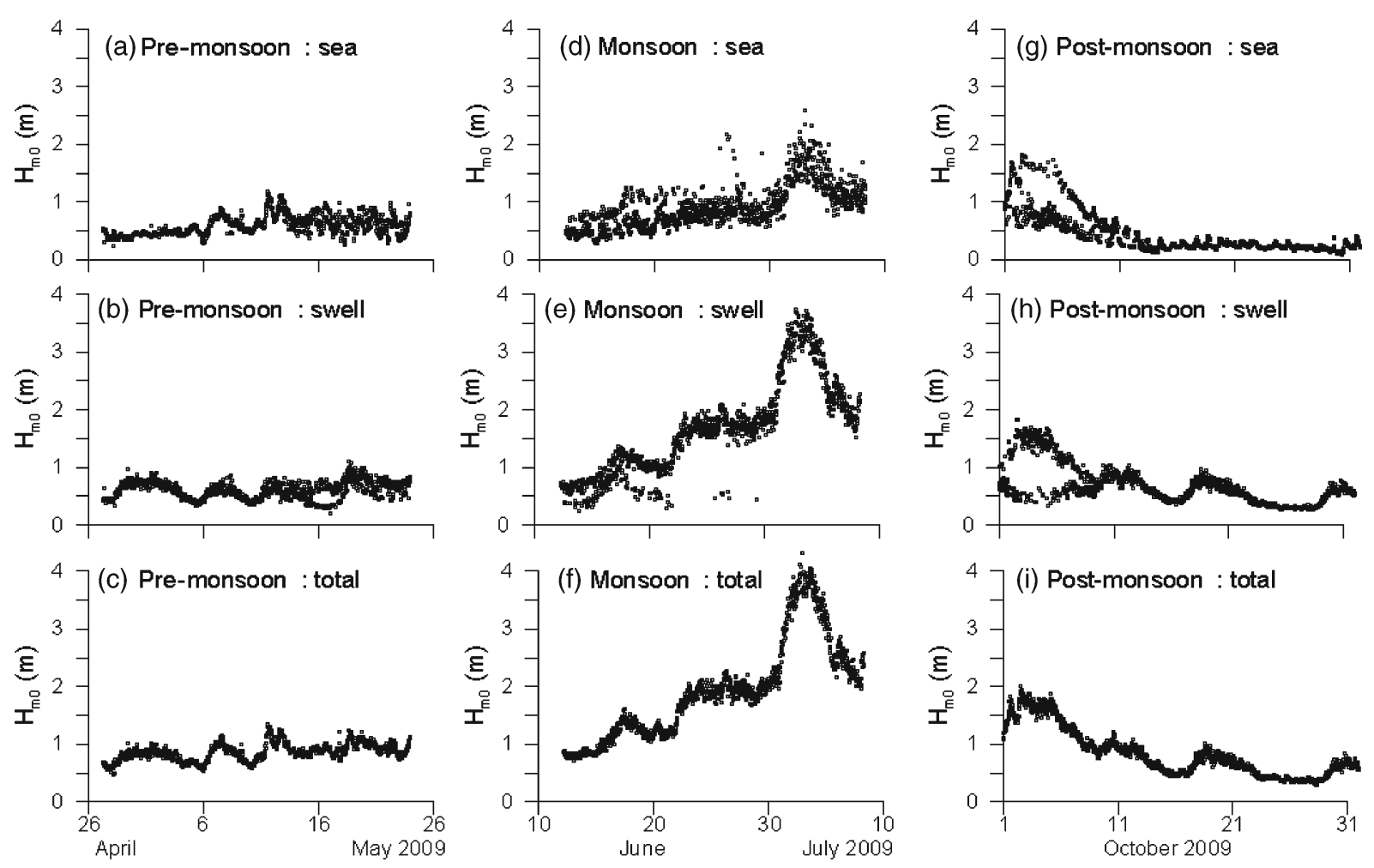

Figure 7. Time series plot of significant wave height of sea, swell and total during pre-monsoon, monsoon and post-monsoon period at Honnavar. 

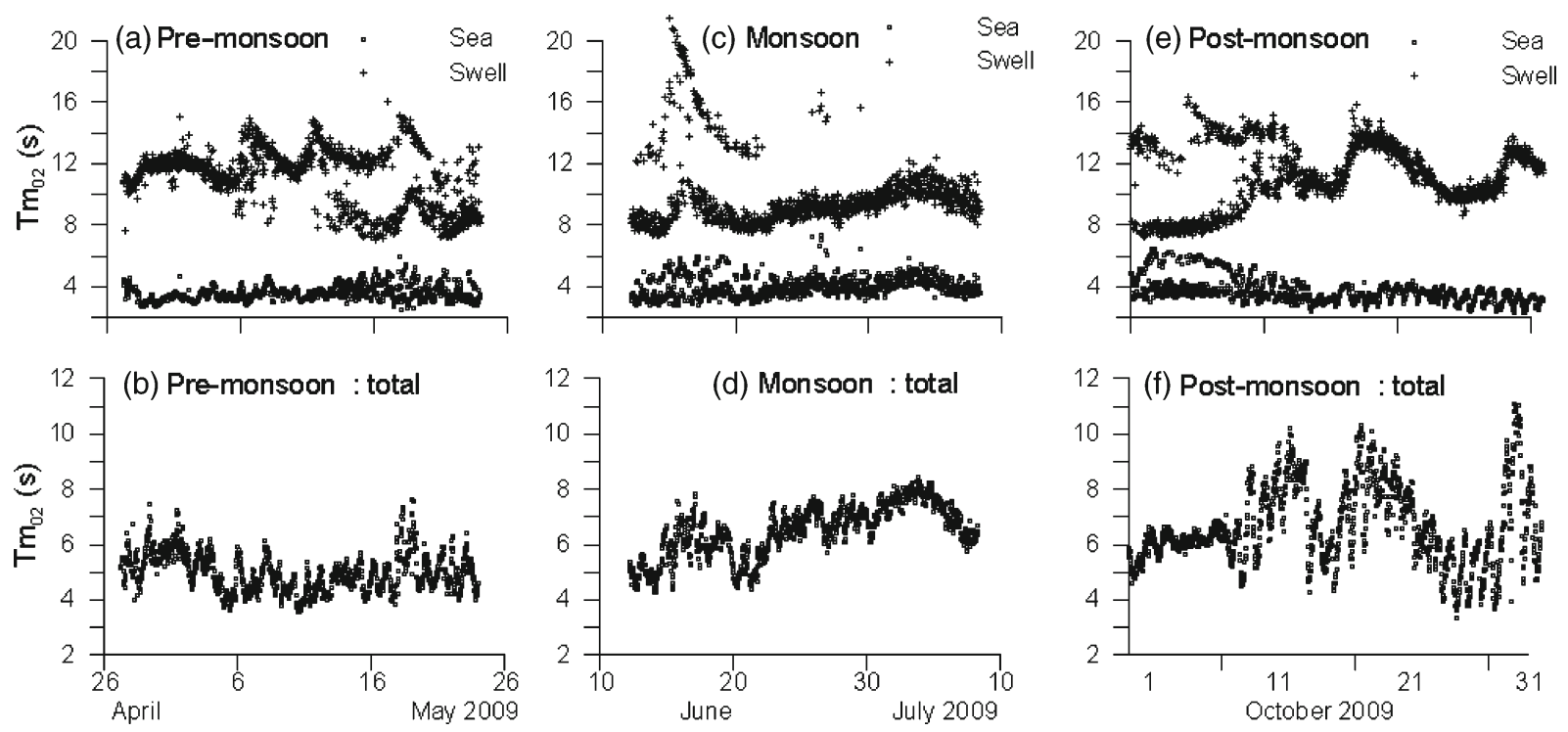

Figure 8. Time series plot of mean wave period of wind sea, swell and total during pre-monsoon, monsoon and post-monsoon period at Honnavar.
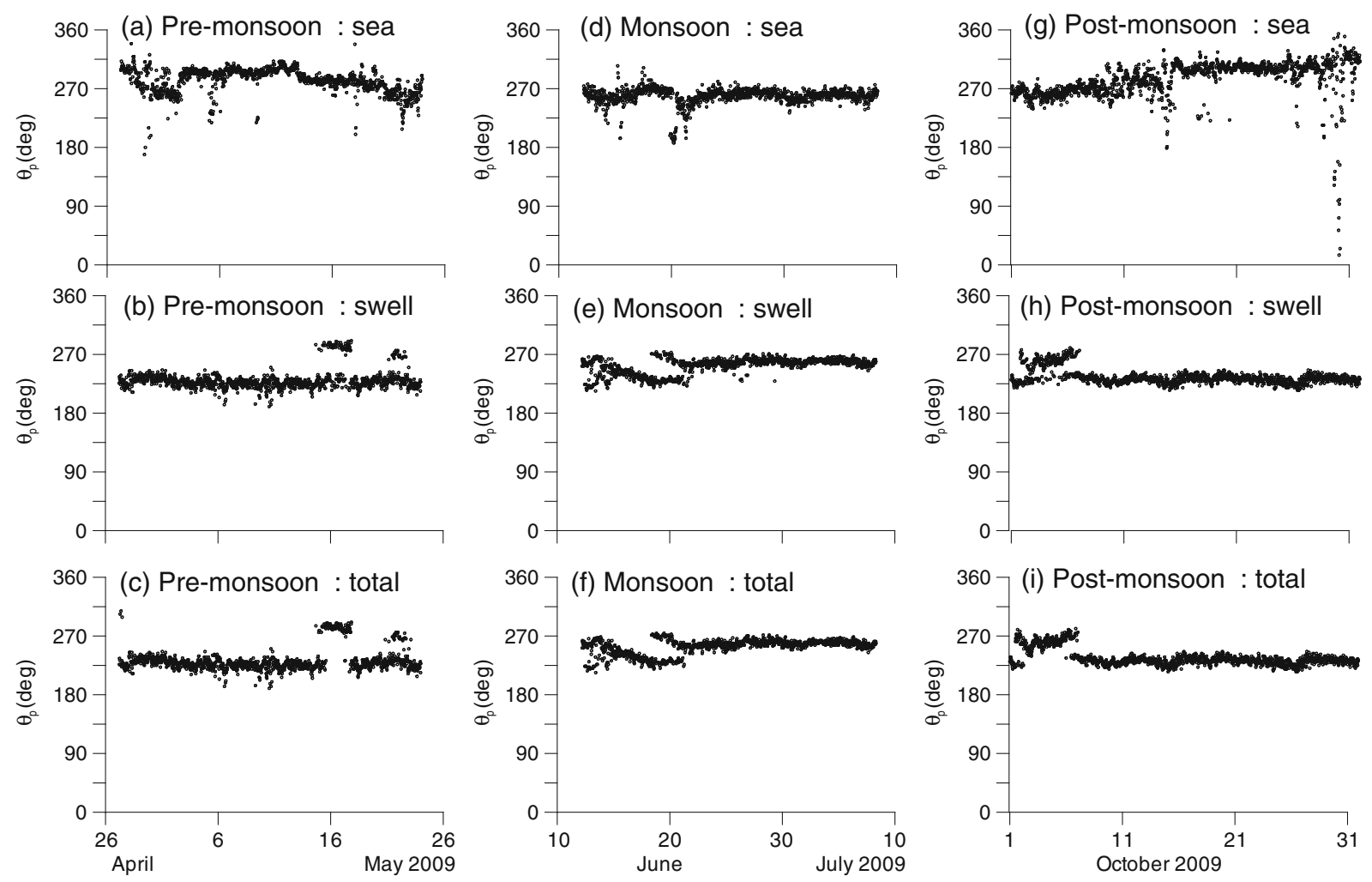

Figure 9. Time series plot of mean wave direction of wind sea, swell and total during pre-monsoon, monsoon and postmonsoon period at Honnavar.

three years (2008-2010). The reason for dominance of swells is expected to be due to

i) the region of the observations is on an open coast and ii) even though the wind at the region is strong during this period, the wind blowing over the entire Arabian Sea is stronger (see figure 1) and the waves generated over the open Arabian Sea will be propagating towards the coast. 
Table 1. Range and average value of the wave parameters at three locations during three different seasons.

\begin{tabular}{|c|c|c|c|c|c|c|c|}
\hline \multirow[t]{2}{*}{ Parameter } & \multirow[t]{2}{*}{ Location } & \multicolumn{2}{|c|}{ Pre-monsoon } & \multicolumn{2}{|c|}{ Monsoon } & \multicolumn{2}{|c|}{ Post-monsoon } \\
\hline & & Range & Average & Range & Average & Range & Average \\
\hline \multirow[t]{3}{*}{$H_{m 0}$ sea $(\mathrm{m})$} & Karwar & $0.2-1.0$ & 0.5 & $0.2-2.1$ & 0.8 & $0.1-1.5$ & 0.3 \\
\hline & Honnavar & $0.2-1.2$ & 0.6 & $0.3-2.6$ & 0.9 & $0.1-1.8$ & 0.4 \\
\hline & Malpe & $0.2-1.1$ & 0.6 & $0.3-2.3$ & 0.9 & $0.1-1.7$ & 0.4 \\
\hline \multirow[t]{3}{*}{$H_{m 0}$ swell $(\mathrm{m})$} & Karwar & $0.3-0.9$ & 0.5 & $0.2-3.2$ & 1.4 & $0.3-1.4$ & 0.6 \\
\hline & Honnavar & $0.2-1.1$ & 0.6 & $0.2-3.7$ & 1.6 & $0.3-1.8$ & 0.7 \\
\hline & Malpe & $0.3-1.0$ & 0.6 & $0.3-3.9$ & 1.7 & $1.1-1.7$ & 0.6 \\
\hline \multirow[t]{3}{*}{$H_{m 0}(\mathrm{~m})$} & Karwar & $0.5-1.2$ & 0.8 & $0.6-3.6$ & 1.6 & $0.3-1.6$ & 0.7 \\
\hline & Honnavar & $0.5-1.4$ & 0.9 & $0.7-4.3$ & 1.9 & $0.3-2.0$ & 0.8 \\
\hline & Malpe & $0.5-1.2$ & 0.8 & $0.8-4.2$ & 1.9 & $0.3-1.9$ & 0.8 \\
\hline \multirow[t]{3}{*}{$T m_{02}$ sea $(\mathrm{s})$} & Karwar & $2.5-5.6$ & 3.5 & $2.6-6.0$ & 3.9 & $2.1-6.5$ & 3.5 \\
\hline & Honnavar & $2.5-5.9$ & 3.6 & $2.8-6.4$ & 4.0 & $2.3-6.5$ & 3.7 \\
\hline & Malpe & $2.4-5.3$ & 3.5 & $2.7-6.0$ & 4.0 & $2.2-6.0$ & 3.4 \\
\hline \multirow[t]{3}{*}{$T m_{02}$ swell (s) } & Karwar & $7.2-15.3$ & 10.6 & $7.6-20.7$ & 9.9 & $7.2-17.1$ & 11.5 \\
\hline & Honnavar & $7.0-16.0$ & 11.1 & $7.4-21.4$ & 9.9 & $7.2-16.3$ & 11.3 \\
\hline & Malpe & $6.9-15.2$ & 10.9 & $7.1-21.0$ & 9.7 & $7.0-16.6$ & 10.7 \\
\hline \multirow[t]{3}{*}{$T m_{02}(\mathrm{~s})$} & Karwar & $3.5-7.1$ & 5.0 & $3.9-8.3$ & 6.5 & $4.1-11.9$ & 7.7 \\
\hline & Honnavar & $3.5-7.6$ & 5.0 & $4.3-8.4$ & 6.5 & $3.4-11.1$ & 6.6 \\
\hline & Malpe & $3.3-7.1$ & 4.8 & $4.1-8.4$ & 6.4 & 2.9-10 & 5.9 \\
\hline \multirow[t]{3}{*}{$T p(\mathrm{~s})$} & Karwar & $3.7-18.2$ & 11.8 & $7.1-22.2$ & 12.3 & $6.3-20$ & 13.2 \\
\hline & Honnavar & $4.8-18.2$ & 12.8 & $6.7-25$ & 11.8 & $6.3-18.2$ & 12.7 \\
\hline & Malpe & $3.1-18.2$ & 12.8 & $6.7-22.2$ & 11.3 & $5.3-18.2$ & 12.4 \\
\hline \multirow[t]{3}{*}{$H_{\max }(\mathrm{m})$} & Karwar & $0.7-1.9$ & 1.2 & $0.8-5.9$ & 2.4 & $0.4-3.0$ & 1.1 \\
\hline & Honnavar & $0.7-2.2$ & 1.3 & $1.0-6.9$ & 2.9 & $0.4-3.6$ & 1.3 \\
\hline & Malpe & $0.7-2.2$ & 1.3 & $1.1-7.1$ & 3.0 & $0.5-3.5$ & 1.2 \\
\hline \multirow[t]{3}{*}{$T_{H \max }(\mathrm{s})$} & Karwar & $3.2-18.8$ & 9.0 & 4.8-19 & 9.9 & $5.7-17.6$ & 11.9 \\
\hline & Honnavar & $3.3-17.4$ & 9.5 & $4.9-20.9$ & 9.7 & $3.9-17.8$ & 11.3 \\
\hline & Malpe & $2.7-16.3$ & 9.5 & $4.9-18.1$ & 9.2 & $2.6-18.3$ & 10.8 \\
\hline \multirow[t]{3}{*}{$\theta$ p sea $(\operatorname{deg})$} & Karwar & 191-302 & 279 & $215-301$ & 260 & 58-336 & 267 \\
\hline & Honnavar & 169-339 & 282 & $187-305$ & 259 & $15-354$ & 285 \\
\hline & Malpe & $65-316$ & 286 & 176-309 & 260 & 7-359 & 284 \\
\hline \multirow[t]{3}{*}{$\theta$ p swell (deg) } & Karwar & $200-286$ & 230 & $214-273$ & 248 & $186-274$ & 230 \\
\hline & Honnavar & $190-291$ & 230 & $214-274$ & 253 & $215-280$ & 235 \\
\hline & Malpe & $121-301$ & 213 & $188-287$ & 253 & $184-288$ & 230 \\
\hline \multirow[t]{3}{*}{$\theta \mathrm{p}(\mathrm{deg})$} & Karwar & $203-295$ & 234 & $214-278$ & 249 & $186-274$ & 231 \\
\hline & Honnavar & $190-308$ & 233 & $214-274$ & 254 & $215-281$ & 237 \\
\hline & Malpe & $121-311$ & 216 & $196-287$ & 255 & $184-291$ & 232 \\
\hline \multirow[t]{3}{*}{$\nu$} & Karwar & $0.43-0.86$ & 0.61 & $0.43-0.85$ & 0.57 & $0.35-0.98$ & 0.63 \\
\hline & Honnavar & $0.43-0.89$ & 0.63 & $0.38-0.85$ & 0.54 & $0.33-0.97$ & 0.65 \\
\hline & Malpe & $0.44-0.90$ & 0.63 & $0.37-0.80$ & 0.53 & $0.41-0.98$ & 0.68 \\
\hline \multirow[t]{3}{*}{ Percentage of sea } & Karwar & $14-84$ & 48 & $16-59$ & 27 & 3-71 & 21 \\
\hline & Honnavar & $15-79$ & 49 & $16-59$ & 28 & $3-71$ & 28 \\
\hline & Malpe & $19-83$ & 50 & $14-67$ & 29 & $7-76$ & 29 \\
\hline \multirow[t]{3}{*}{ Percentage of swell } & Karwar & $16-86$ & 52 & $41-84$ & 73 & $29-97$ & 79 \\
\hline & Honnavar & $21-85$ & 51 & $41-84$ & 72 & 29-97 & 72 \\
\hline & Malpe & $17-81$ & 50 & $33-86$ & 71 & $24-93$ & 71 \\
\hline
\end{tabular}

When these swells are added to the wave system at the measurement location, the relative energy of the wind sea reduces and that of the swell increases. Even though dominance of swells was found during monsoon, the average swell period (9.9 s) during monsoon is less than the average swell wave period during other seasons $(11.3 \mathrm{~s}$ in post-monsoon and $11.1 \mathrm{~s}$ in pre-monsoon). During the monsoon, the average period of swell is reduced due to the increase in the number of young swells having period 6-10 s, which are generated in the Arabian Sea. During the other periods, the old or 
matured swells having period more than $10 \mathrm{~s}$ dominate. Waves in shallow water location off the west coast of India during the onset of summer monsoon (Kumar et al 2010) were mainly swells arriving from the south and south-west direction. Kumar et al (2011b) found that $75 \%$ of the wave height in the northern Arabian Sea close to Gujarat coast during the monsoon was due to the swells arriving from the south-west and the remaining was due to the seas from south-west to north-west.

The variations in mean $H_{m 0}$ between the three locations are $10-15 \%$ and the variations in $H_{\max }$ is 10-20\%. The average value of $H_{m 0}$ varied between 0.8 and $0.9 \mathrm{~m}$ during pre-monsoon at the three locations indicating that the wave fields at different locations along the $200 \mathrm{~km}$ long stretch of the west coast of India are similar. Waves at Karwar were slightly less than that at other two locations with average $H_{m 0}$ of $1.6 \mathrm{~m}$ at Karwar and $1.9 \mathrm{~m}$ at other locations during monsoon. This could be due to the fact that at Karwar the waves were measured at $7 \mathrm{~m}$ depth contour whereas the measurements at other two locations were at $9 \mathrm{~m}$. The average of the mean wave period $\left(T m_{02}\right)$ of sea was $3.5 \mathrm{~s}$ during pre- and post-monsoon and was $4 \mathrm{~s}$ during the monsoon (figure 8). Average $T m_{02}$ was $5 \mathrm{~s}$ during pre-monsoon and $6.5 \mathrm{~s}$ during the monsoon. $T m_{02}$ was relatively high during the postmonsoon period. Variations in $T m_{02}$ between the three locations are around 10\%. During monsoon and post-monsoon periods, the measured waves were predominantly swells arriving from south and south-west. During pre-monsoon period the waves were predominantly from south-west to north-west (figure 9). The average coastal inclination of the study region is $17^{\circ}$ to the west from the true north. Waves having direction $253^{\circ}$ will be approaching perpendicular to the coast (wave crest angle will be parallel to the coastline). The average difference between the sea and swell direction was less during the monsoon $\left(\sim 8^{\circ}\right)$ and was $\sim 60^{\circ}$ during the pre-monsoon period and $\sim 50^{\circ}$ during the postmonsoon period. Except during monsoon, when the swells break in the surf zone, northerly longshore currents will be generated and when the seas break, southerly longshore currents will be generated. During monsoon the wave crest angle will be parallel to the coast and when the waves break, predominant onshore-offshore currents will be generated. Hence the predominant movement of sediment transport along the Karnataka coast during monsoon will be offshore-onshore. The study shows that the wave statistical parameters do not vary significantly between the locations studied and hence the measurement at one location will be sufficient to determine the design parameters of marine structures anywhere in the same depth contour along the Karnataka coast.
Significant wave height $\left(H_{1 / 3}\right)$ based on zero crossing analysis was found to be $3.6 \sqrt{ } m_{0}$. In practice, $H_{m 0}$ is operationally defined as $4 \sqrt{ } m_{0}$. Goda (1979) analysed field data and found that for winddriven waves in deep water, $H_{1 / 3}$ is approximately $3.8 \sqrt{ } m_{0}$ instead of the narrow-band value of $4 \sqrt{ } m_{0}$, which gives a reduction of $5 \%$ in estimation of $H_{1 / 3}$. The reduction in present case is $10 \%$ and the reduction is due to the presence of wind seas and swells in the measured data which makes the wave spectrum relatively broad-banded. Also the shallow water spectrum will be broad-banded than a deep water spectrum (Kumar et al 2007). During the measurements, the spectral narrowness parameter $(\nu)$ had a mean value of around 0.6 with relatively low values during the monsoon compared to other periods indicating that the spectrum is narrow-banded during the monsoon.

Guedes Soares et al (2004) showed that in addition to individual wave parameters, the asymmetry of waves can be described by the statistics of the time series (skewness). Linear sea states will have no skewness with equal wave crest and trough equivalent to half the wave height. Positive skewness values indicate that the wave crests are bigger than the troughs. Present study showed that the skewness varied from -0.13 to 0.7 . During monsoon, high skewness values $(\sim 0.2)$ were observed, i.e., the crest height is bigger than the troughs. Crest height is an important parameter in the design of the air gap for the marine structures. In the absence of measured data, it is generally assumed that the wave crest and trough are equal and is half the wave height.

The water depth at the wave measurement locations at Malpe and Honnavar was $9 \mathrm{~m}$ and at Karwar was $7 \mathrm{~m}$. Hence the measured waves are expected to experience depth influence. Average value of the wavelength associated with the mean wave period varied from 33 to $58 \mathrm{~m}$ and the ratio of depth to wavelength $(d / L)$ varied from 0.1 to 0.5 . This indicates that the measured waves were in transitional water. The ratio $(d / L)$ associated with the swells varied from 0.07 to 0.16 . These numbers too indicate that the measured waves were in transitional water. During pre- and post-monsoon period, $50 \%$ of the wind seas were in the deep water condition. During monsoon period, $20 \%$ of the wind seas satisfied the deep water condition. Hence the measured waves were the transformed waves. The measured wave height and the wave direction is, therefore, expected to be different than that in the deep water off the coast.

A number of parameters that define the wave field that the structure has to withstand are needed in the designing of a structure in offshore region. Many of these for the three locations examined here are summarized in table 1 . In addition to 
these parameters the designer often needs the relationship between $H_{m 0}$ and $T m_{02}$. In figure 10, we show this relationship as revealed by the observations reported in this paper. Observations from all the three locations have been used in the figures. Also plotted in the figure is the relationship between $H_{m 0}$ and $T m_{02}$ proposed in Shore Protection Manual (1984). Note that the observed relationship gives $T m_{02}$ corresponding to a $H_{m 0}$ higher than that given in the manual.

Also plotted in figure 10 is an empirical relation $T m_{02}=a H_{m 0}^{b}$, where $a$ and $b$ equals 5.4 and 0.25 , respectively. Earlier, Kumar et al (2010) had found that the same relation is applicable to the data collected off Goa which is located to the north of the area studied here (figure 2). This relation is an
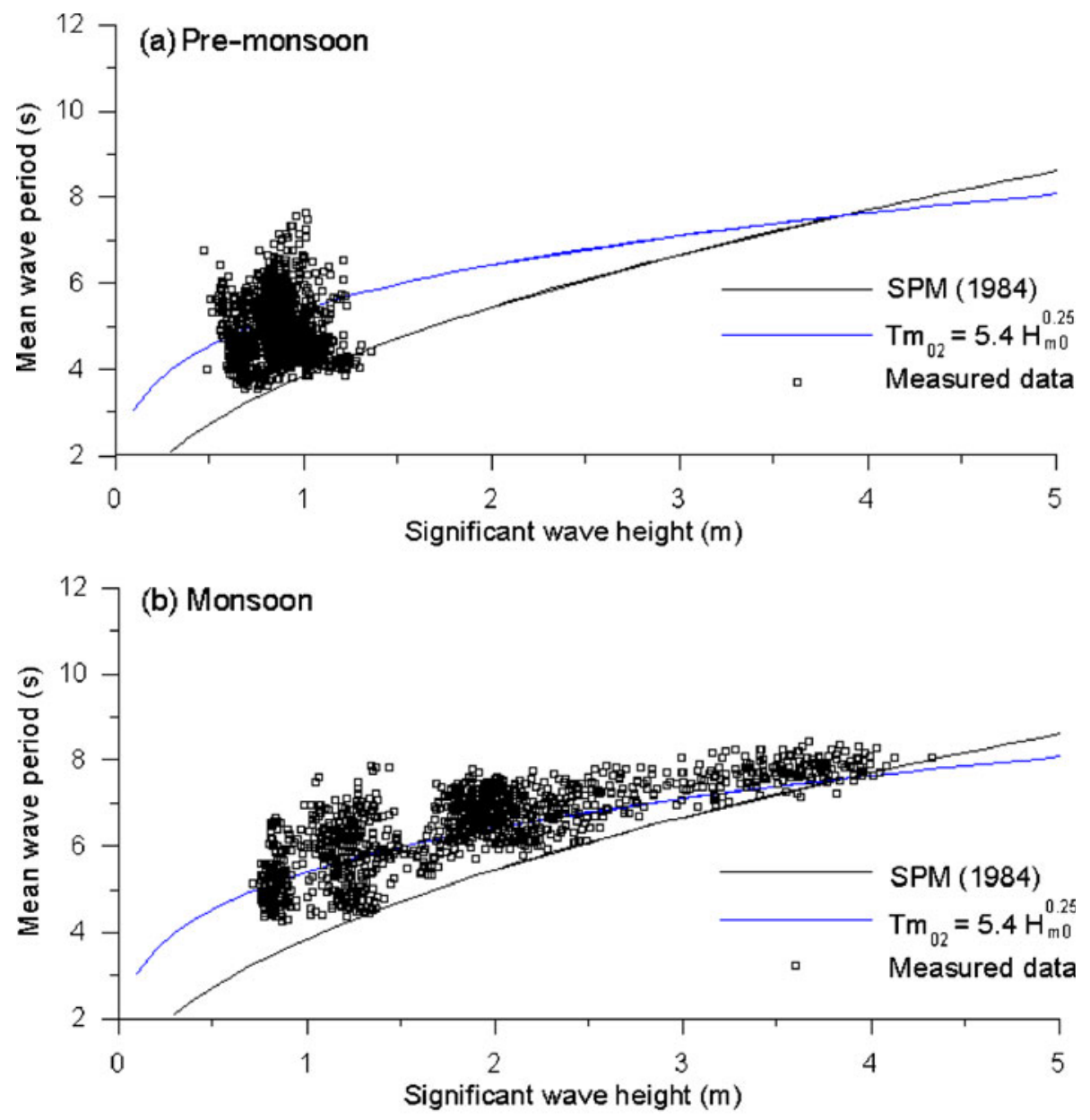

(c) Post-monsoon

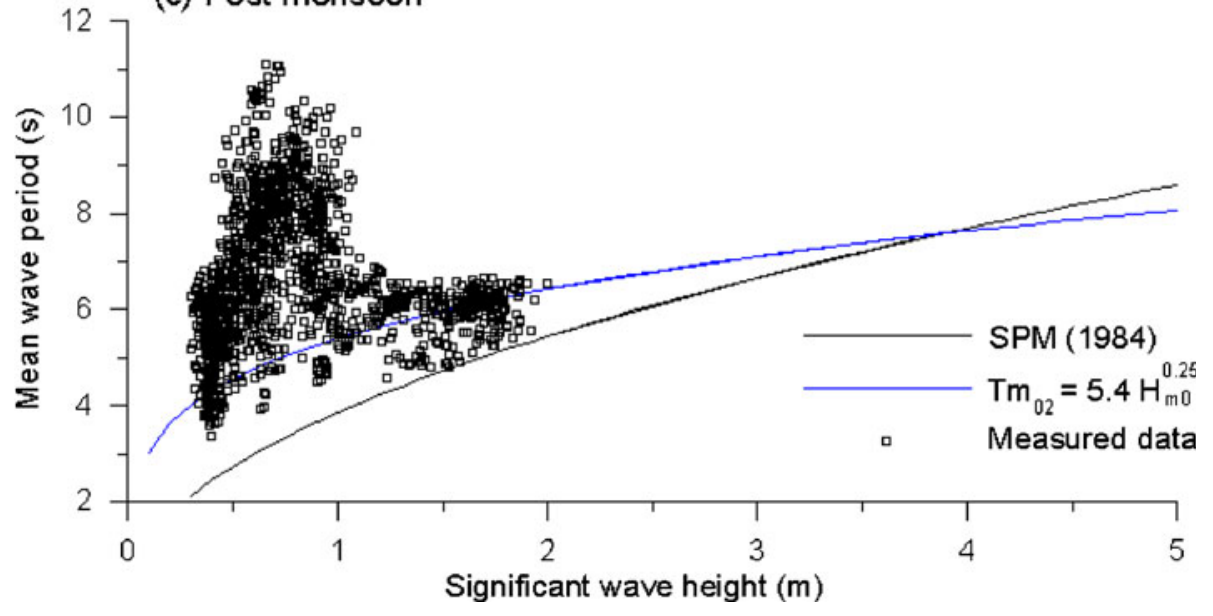

Figure 10. Variation of mean wave period with significant wave height during three different seasons. Observations from all the three locations have been used in the figure. 
improvement over that given in Shore Protection Manual (1984) as can be seen from figure 10.

\section{Acknowledgements}

The authors thank Integrated Coastal and Marine Area Management Project Directorate (ICMAM PD), Ministry of Earth Sciences, New Delhi for funding the measurement program. Dr S R Shetye, Director, National Institute of Oceanography, Goa and $\operatorname{Dr} B$ R Subramanian, Project Director, ICMAM PD, Chennai are thanked for the encouragement provided to carry out the study. They also thank Mr G N Naik and Mr M Mochemadkar for the help provided during the measurement, Mrs Kirti Kedar Dubhashi for the data analysis, and Mr G S Michael for providing figure 1. Authors also extend their thanks to the two reviewers whose suggestions helped to improve the manuscript. This is NIO contribution no. 5063.

\section{References}

Goda Y 1979 A review on statistical interpretation of wave data; In: Report of the Port and Harbour Research Institute, Japan 18 5-32.

Guedes Soares C, Cherneva Z and Antao E M 2004 Steepness and asymmetry of the largest waves in storm sea states; Ocean Eng. 31 1147-1167.

Kumar V S and Anand N M 2004 Variations in wave direction estimated using first and second order Fourier coefficients; Ocean Eng. 31 2105-2119.

Kumar V S, Anand N M, Kumar K A and Mandal S 2003 Multipeakedness and groupiness of shallow water waves along Indian coast; J. Coast. Res. 19 1052-1065.

Kumar V S, Pathak K C, Pednekar P, Raju N S N and Gowthaman R 2006 Coastal processes along the Indian coastline; Curr. Sci. 91(4) 530-536.
Kumar V S, Kumar K A, Pednekar P and Gowthaman R 2007 Sea and swell along west coast of India: Study based on measured data; Proc. Fourth Indian National Conference on Harbour and Ocean Engineering, INCHOE-07, Surathkal, India, pp. 736-745.

Kumar V S, Philip S and Nair T N B 2010 Waves in shallow water off west coast of India during the onset of summer monsoon; Annales Geophysicae 28 817-824.

Kumar V S, Dora G U, Philip S, Pednekar P and Jai Singh 2011a Variations in tidal constituents along the nearshore waters of Karnataka, west coast of India; J. Coast. Res. 27(5) 824-829.

Kumar V S, Jai Singh, Pednekar P and Gowthaman $\mathrm{R} 2011 \mathrm{~b}$ Waves in the nearshore waters of northern Arabian Sea during the summer monsoon; Ocean Eng. 38 $382-388$.

Longuet-Higgins M S 1975 On the joint distribution of the periods and amplitudes of sea waves; J. Geophys. Res. 80 2688-2694.

Neetu S, Shetye Satish and Chandramohan P 2006 Impact of sea breeze on wind-seas off Goa, west coast of India; J. Earth Syst. Sci. 115 229-234.

Pierson W J and Moskowitz L 1964 A proposed form for fully developed seas based on the similarity theory of S A Kitaigorodski; J. Geophys. Res. 69 5181-5190.

Portilla J, Ocampo-Torres F J and Monbaliu J 2009 Spectral partitioning and identification of wind sea and swell; J. Atmos. Oceanic Technol. 26 117-122.

Semedo A, Suselj K, Rutgersson A and Sterl A 2011 A global view on the wind sea and swell climate and variability from ERA-40; J. Climate 24 1461-1479.

Shankar D 2000 Seasonal cycle of sea level and currents along the coast of India; Curr. Sci. 78(3) 279-287.

Shetye S R, Shenoi S S C, Antony A K and Kumar V K 1985 Monthly-mean wind stress along the coast of the north Indian Ocean; J. Earth Syst. Sci. 94 129-137, doi: 10.1007/BF02871945.

Shore Protection Manual: 1984 U S Army Coastal Engineering Research Center, Department of the Army, Corps of Engineers, U.S. Govt. Printing Office, Washington, DC, USA, Vols. 1 and 2.

Stephen F B and Tor Kollstad 1991 Field trials of the directional waverider; Proc. First International Offshore and Polar Engineering Conference, Edinburgh III $55-63$. 